\title{
Disease risks associated with the importation and release of non-native crayfish species into mainland Britain
}

\author{
Matt Longshaw $^{1, *}$, Kelly S. Bateman ${ }^{1}$, Paul Stebbing ${ }^{1}$, Grant D. Stentiford ${ }^{1}$, \\ Frances A. Hockley ${ }^{1,2}$ \\ ${ }^{1}$ Cefas Weymouth Laboratory, The Nothe, Weymouth, Dorset DT4 8UB, UK \\ ${ }^{2}$ Present address: School of Biosciences, Cardiff University, Cardiff CF10 3AX, UK
}

\begin{abstract}
A full histological survey of 782 non-indigenous crayfish established in riverine habitats or imported into mainland Britain through the aquarium trade was conducted. The selected populations were subjected to further bacteriological, molecular and ultrastructural studies to characterise disease conditions. Pacifastacus leniusculus, Orconectes virilis and Astacus leptodactylus were obtained from 16 rivers in mainland Britain. Additionally, Cambarellus patzcuarensis, Cherax quadricarinatus, Procambarus clarkii and P. fallax were obtained from 8 pet shops, whilst C. patzcuarensis, Cherax peknyi, C. quadricarinatus and P. clarkii were seized at a point of entry into Britain. Tests for infections were negative in the majority of $P$. leniusculus $(66.4 \%)$; the rest were infected with at least one pathogen or commensal, including an intranuclear bacilliform virus and a novel Spiroplasma sp. of male Sertoli cells. Low level bacterial and ciliate infections and commensal mites and ostracods also occurred on or in established signal crayfish. The established population of $O$. virilis was found to be negative for any visible infections; one shipment of $P$. clarkii and one aquarium-held population of C. quadricarinatus were also found to contain no visible infections. One shipment of $P$. clarkii from Singapore was infected with white spot syndrome virus (WSSV). The bacterial species isolated from crayfish included Aeromonas hydrophila, A. sobria, Citrobacter freundii, Grimontia hollisae, Hafnia alvei, Pasteurella multocida and Weeksella virosa. The results are discussed in relation to the enemy release hypothesis, and the risk associated with the transboundary trade in non-indigenous crayfish is considered as a potential source of disease to native crayfish species.
\end{abstract}

KEY WORDS: Crustacean hosts $\cdot$ Virus $\cdot$ Parasite $\cdot$ Transboundary disease $\cdot$ Live animal trade Enemy release hypothesis

\section{INTRODUCTION}

The deliberate or accidental release of an alien species into a new area brings with it the risk of altering the community structure of native populations through competition, predation, habitat alteration or disease transfer (Calvo-Ugarteburu \& McQuaid 1998). Introduced species may be successful in establishing in a new area and becoming invasive if they are released from control by their natural enemies, including disease agents (Clay 2003). If an alien species successfully establishes in a new area, it can either lose or leave behind some or all of its parasites and diseases (Torchin et al. 2003) or acquire indigenous parasites after introduction, with either a limited impact or an enhancement of their invasiveness (Dick et al. 2010). The enemy release hypothesis, whereby an alien host advantageously loses its parasites, has been used to explain the establishment success of a number of invasive species in terrestrial and 
aquatic ecosystems (Torchin et al. 2001). Torchin et al. (2003), in reviewing the literature on species introductions, suggested that whilst on average 16 parasite species were recorded from native populations, only an average of 3 parasite species successfully accompanied an invader to its introduced range. Alien species subsequently only acquire an average of 4 'native' pathogens. The invasive European shore crab Carcinus maenas is host to a number of parasites that are known to affect its growth, mortality and reproduction in its native range; in its invasive range, where it is a major pest species, the crabs were less parasitized and larger, suggesting that survival or growth was improved as a direct result of the loss of its parasite fauna (Torchin et al. 2001).

Holdich et al. (2009) listed 10 non-indigenous crayfish species (NICS) that are established in European waterways, compared with only 5 indigenous crayfish species (ICS). The 3 most widespread NICS in Europe, Pacifastacus leniusculus, Orconectes limosus and Procambarus clarkii, are of North American origin and were introduced prior to 1975 (Holdich et al. 2009). Astacus leptodactylus from eastern Europe and Cherax quadricarinatus from Australia have a narrower geographical range but are still considered detrimental to ecosystems (Holdich et al. 2009, Savini et al. 2010). The concern regarding invasive crayfish species has been in part due to competition between NICS and ICS but also because some invasive species are potential carriers of Aphanomyces astaci, the causative agent of so-called crayfish plague (Alderman et al. 1990). Non-indigenous crayfish have been moved into Europe via the aquaculture and aquarium trades. Subsequently, the deliberate or accidental release of NICS into the environment has allowed some of them to become established in Europe and other parts of the world (Belle \& Yeo 2010).

Numerous disease conditions and parasites of crayfish have been reported in the literature (for reviews, see Edgerton et al. 2002 and Longshaw 2011). However, as noted by Longshaw (2011), the profile of parasites and pathogens described in each report often reflect the particular interest of specific researchers rather than a true representation of the full range of pathogens present. For example, whilst Cambarellus patzcuarensis is listed as a host for 24 ciliate species, no other infections have been reported (MayénEstrada \& Aladro-Lubel 2001). Likewise, in describing the reproductive elements of the marble crayfish Procambarus fallax, Vogt et al. (2004) described a coccidian and a Rickettsia-like organism. Although no further disease surveys of marbled crayfish have been conducted, Martin et al. (2010) suggested that the species may be capable of transmitting Aphanomyces astaci and should therefore be considered a threat to native crayfish species, particularly because modelling studies suggest that it will be able to successfully establish in a number of countries, including the USA, Madagascar and parts of Europe (Feria \& Faulkes 2011). P. clarkii in the USA has been recorded as a host for Psorospermium spp., 8 species of Digenea, at least 3 ciliate species, several branchiobdellids and the acanthocephalan Southwellina dimorpha (Edgerton et al. 2002, Longshaw 2011). P. clarkii transferred to Italy were recorded as hosts for a small number of 'native' pathogens, including ostracods, nematodes and branchiobdellids as well as Cambarincola mesochoreus from the USA (Gelder et al. 1999, Quaglio et al. 2006), whilst $P$. clarkii in China were noted as being infected with a systemic Spiroplasma sp. (Bi et al. 2008) and white spot syndrome virus (WSSV) (Du et al. 2008). Baumgartner et al. (2009) noted the presence of WSSV in wild populations of $P$. clarkii in the USA.

The present study describes the results of a disease survey of non-native crayfish species that are either established in freshwater ecosystems in mainland Britain, seized from commercial pet shops or seized at border inspection posts (BIPs) at a point of entry into the country. The data is put into the context of the enemy release hypothesis, and the wider risks associated with the transboundary trading of nonnative crayfish for indigenous species as well as disease risks to non-indigenous species from native pathogens are considered.

\section{MATERIALS AND METHODS}

\section{Crayfish collection and measurements}

Sixteen Pacifastacus leniusculus populations in 15 rivers, one Orconectes virilis population and one Astacus leptodactylus population within Britain were sampled using traps between July 2007 and November 2010 (see Table 1). In addition, Cambarellus patzcuarensis, Cherax quadricarinatus, Procambarus clarkii and P. fallax were seized from 8 pet shops in England, whilst illegally imported C. quadricarinatus and P. clarkii from Singapore and Cherax peknyi from Indonesia and Singapore were seized at the BIP at Manchester Airport (see Table 2).

Live crayfish were examined for external conditions, including fouling and damage to carapace and legs, then placed on ice for $\sim 20 \mathrm{~min}$ to euthanize them prior to sampling for histology, electron microscopy, bacteriology and molecular studies. 


\section{Screening for bacteriology}

Approximately $2 \mathrm{ml}$ of haemolymph was collected from selected populations of crayfish and mixed with an equal volume of neutral buffered formalin, smeared onto a slide and left to air dry. These slides were subsequently stained using May-Grünwald Giemsa stain. A further sample of haemolymph was swabbed onto tryptic soy agar (TSA) plates and incubated at $22^{\circ} \mathrm{C}$ for up to $24 \mathrm{~h}$. Any bacterial colonies developing after $24 \mathrm{~h}$ were re-plated onto TSA plates. Pure bacterial isolates were identified using a series of biochemical and morphological tests, including catalase, oxidase, morphology and motility. In addition, the isolates were further identified using the API (Biomerieux) system. Oxidase-positive isolates were identified with the 20NE system, and oxidase-negative isolates were identified with the $20 \mathrm{E}$ system.

\section{Histological screening}

Crayfish with a carapace length $<5 \mathrm{~cm}$ were fixed whole in Davidson's freshwater fixative. Larger animals were dissected, and samples of the carapace, abdominal and cheliped muscle, gill, gonad and hepatopancreas were preserved in Davidson's freshwater fixative for $24 \mathrm{~h}$ then transferred to $70 \%$ industrial methylated spirits (IMS). If required, the tissue samples were decalcified in a rapid decalification solution. The tissues were processed to wax blocks using an automatic vacuum infiltration tissue processor (Vision Biosystems Peloris). Sections were cut at 3 to $5 \mu \mathrm{m}$ and routinely stained with haematoxylin and eosin (H\&E) in an automatic tissue stainer. The tissues were examined on a light microscope using brightfield illumination. A record was made of any pathologies or pathogens in tissues and, where appropriate, an indication of the level of infection severity. Images were captured using a LUCIA ${ }^{\mathrm{TM}}$ (Nikon) screen measurement system.

\section{Electron microscopy}

Small cubes measuring 1 to $2 \mathrm{~mm}^{3}$ of hepatopancreas were fixed in $2.5 \%$ glutaraldehyde in $0.1 \mathrm{M}$ sodium cacodylate buffer ( $\mathrm{pH}$ 7.4) for $2 \mathrm{~h}$ at room temperature. In addition, the tissue samples were processed for transmission electron microscopy (TEM) from wax blocks, and the tissue of interest was identified and cut from the wax block. The tissue was dewaxed, rehydrated and rinsed thoroughly in $0.1 \mathrm{M}$ sodium cacodylate buffer ( $\mathrm{pH} 7.4$ ) before being fixed in $2.5 \%$ glutaraldehyde in $0.1 \mathrm{M}$ sodium cacodylate buffer as above. The fixed tissue samples were rinsed in $0.1 \mathrm{M}$ sodium cacodylate buffer and post-fixed for $1 \mathrm{~h}$ in $1 \%$ osmium tetroxide in $0.1 \mathrm{M}$ sodium cacodylate buffer. The specimens were washed in 3 changes of $0.1 \mathrm{M}$ sodium cacodylate buffer before dehydration through a graded acetone series. The specimens were embedded in Agar 100 epoxy resin (Agar Scientific, Agar 100 pre-mix kit, medium) and polymerised overnight at $60^{\circ} \mathrm{C}$ in an oven. Semi-thin (1 to $\left.2 \mu \mathrm{m}\right)$ sections were stained with Toluidine Blue for viewing with a light microscope to identify suitable target areas. Ultrathin sections (70 to $90 \mathrm{~nm}$ ) of these areas were mounted on uncoated copper grids and stained with $2 \%$ aqueous uranyl acetate and Reynolds' lead citrate (Reynolds 1963). Grids were examined using a JEOL JEM 1210 transmission electron microscope, and digital images were captured using a Gatan Erlangshen ES500W camera and Gatan Digital Micrograph $^{\mathrm{TM}}$ software. In a small number of cases, the wax-embedded tissue blocks were reprocessed for electron microscope studies according to the methods of Watson et al. (1972). Sections were stained with lead citrate and uranyl acetate and examined on a JEOL JEM 1210 as above.

\section{Molecular screening}

Samples of gonad, muscle, gill and hepatopancreas tissue were preserved in ethanol. In addition, bacterial colonies for molecular identification were emulsified in molecular-grade water containing $1 \mathrm{ml} \mathrm{DNAzol}{ }^{\circledR}$ and centrifuged at $4472 \times g$ for $10 \mathrm{~min}$. The supernatant was resuspended in $99.9 \%$ ethanol and centrifuged for a further $30 \mathrm{~min}$, after which the supernatant was discarded, and the pellet was resuspended in molecular-grade water and heated to $65^{\circ} \mathrm{C}$. Samples were lysed in $44 \mathrm{\mu l}$ of $1 \%$ sodium dodecyl sulphate (SDS), $5 \mu \mathrm{l}$ of Proteinase $\mathrm{K}\left(20 \mu \mathrm{ml}^{-1}\right)$ and $400 \mu \mathrm{l}$ of Tris-ethylenediaminetetraacetic (TE) buffer for $1 \mathrm{~h}$ at $60^{\circ} \mathrm{C}$. The samples were then extracted twice with $400 \mu \mathrm{l}$ of phenol/chloroform/isoamyl alcohol (50:50:1) and $40 \mu \mathrm{l}$ of $3 \mathrm{M}$ sodium acetate. Genomic DNA was precipitated in absolute ethanol and centrifuged at $13000 \times g$ for $15 \mathrm{~min}$, and the ethanol was removed. The resultant pellet was airdried, resuspended in $20 \mu \mathrm{l}$ of RNase/DNase-free water and stored at $-20^{\circ} \mathrm{C}$. The bacterial $16 \mathrm{~S}$ rDNA was amplified by a single-round PCR using the primers $8 \mathrm{~F}$ (5'-AGA GTT TGA TCC TGG CTC AG-3') and 536R (5'-GWA TTA CCG CGG CKG CTG-3'). The PCR was 


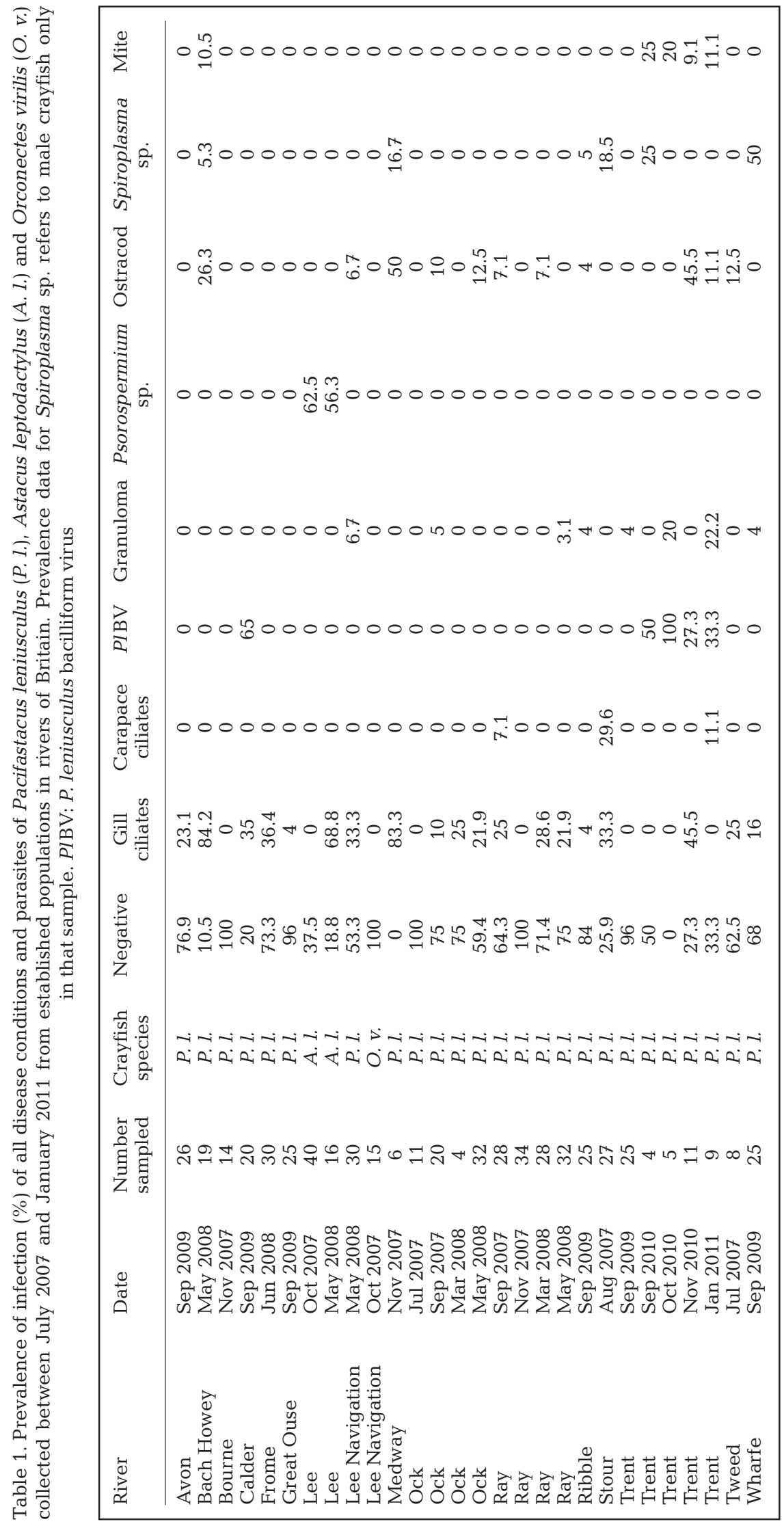

performed in standard $100 \mu$ reactions (containing tris- $\mathrm{HCl}$ buffer, $2.5 \mathrm{U}$ of Taq DNA polymerase, $200 \mu \mathrm{M}$ of each deoxynucleoside triphosphate, $1.5 \mathrm{mM}$ $\mathrm{MgCl}_{2}, 0.1 \mu \mathrm{M}$ of both primers and distilled water), and the temperatures were cycled in a Stratagene Robocycler 40. A total of 35 cycles of $1 \mathrm{~min}$ at $95^{\circ} \mathrm{C}$, $1 \mathrm{~min}$ at $55^{\circ} \mathrm{C}$, and $1 \mathrm{~min}$ at $72^{\circ} \mathrm{C}$ were used in the amplification. The process was ended by a 10 min extension at $72^{\circ} \mathrm{C}$. The PCR products were resolved for $20 \mathrm{~min}$ at $140 \mathrm{~V}$ on a $2 \%$ agarose gel containing ethidium bromide. The DNA was visualised with UV light, and the DNA fragment of interest was excised from the agarose gel and separated from the agarose using the Wizard ${ }^{\circledR}$ SV Gel and PCR Clean-up system following the manufacturer's protocol. The template DNA was cycle sequenced at $94^{\circ} \mathrm{C}$ for $30 \mathrm{~s}, 96^{\circ} \mathrm{C}$ for $10 \mathrm{~s}, 50^{\circ} \mathrm{C}$ for $10 \mathrm{~s}$, and $60^{\circ} \mathrm{C}$ for $4 \mathrm{~min}$ for 30 cycles and then held at $4^{\circ} \mathrm{C}$. The samples were then run through a sequencer, and sequences were analysed with WU-BLAST2 to identify bacterial species. The molecular identification of WSSV followed standard protocols as defined by the Office International des Epizooties Manual of Diagnostic Tests for Aquatic Animals (OIE 2009).

\section{RESULTS}

\section{Health status of established non-native crayfish}

A total of 498 signal crayfish Pacifastacus leniusculus were collected from 16 sites on 15 rivers in Britain; of these, 331 were negative for any infections (prevalence of $66.4 \%$ ). All of the signal crayfish collected from the River Ray in November 2007, the River Ock in July 2007 and the River Bourne in November 2007 were negative for infections. The crayfish populations from the remaining sites contained at least one animal infected with a pathogen. Prevalence data for signal crayfish infections are shown in Table 1. 


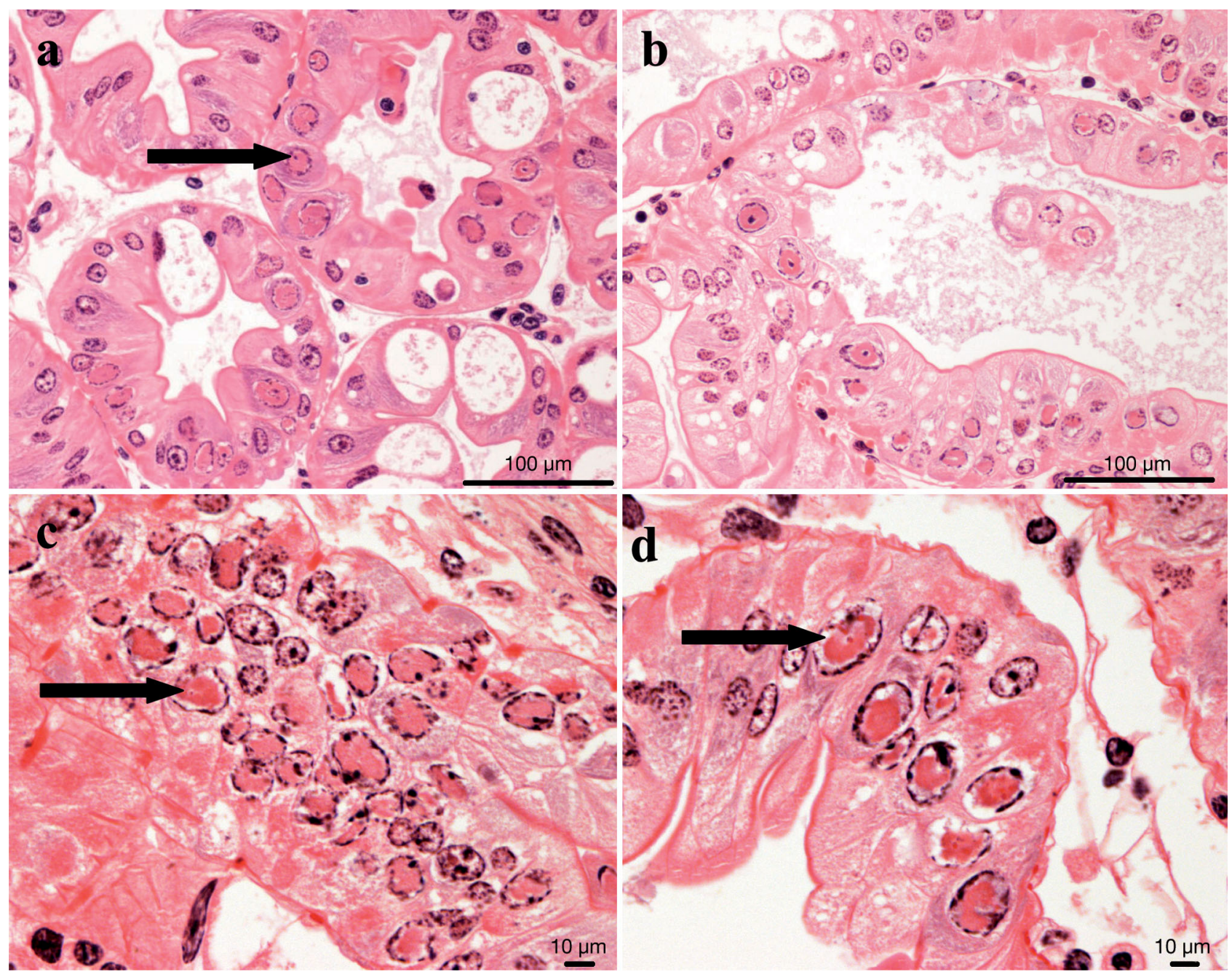

Fig. 1. Pacifastacus leniusculus bacilliform virus (PIBV) within epithelial cells of crayfish hepatopancreas tissues, based on H\&E staining. (a) Low power view of several hepatopancreatic tubule epithelial cell nuclei showing typical enlarged appearance with emarginated chromatin and large eosinophilic inclusion (arrow). (b) Hepatopancreatic tubule infected with PlBV. Note the presence of a sloughed area of tubule cells in tubule lumen. (c) High power view of PlBV-infected hepatopancreatic tubule. Infected nucleus marked with arrow. (d) High power view of PIBV-infected hepatopancreatic tubule. Note emarginated chromatin and inclusion body typical of infection in signal crayfish (arrow)

An intranuclear bacilliform viral infection of the midgut epithelium and the hepatopancreas was noted in 4 out of 5 samples of Pacifastacus leniusculus from the River Trent at prevalences up to $100 \%$ and from $65 \%$ of signal crayfish collected from the River Calder in September 2009. The nuclei of the affected hepatopancreatocytes were enlarged with emarginated chromatin (Fig. 1). In a small number of individuals, some of the infected cells were sloughed into the tubule lumina (Fig. 1c). Electron microscopy revealed multiple infected nuclei; the host chromatin was marginalised, and the nuclear membrane appeared swollen (Fig. 2a). Fully formed virions appeared to accumulate at the nuclear membrane in some nuclei, forming paracrystalline arrays (Fig. 2b), and were rod shaped, consisting of an electron-dense nucleocapsid surrounded by a closely fitting trilaminar membrane (Fig. 2C,d). The virions measured on average $228.8 \mathrm{~nm}$ in length and $71.9 \mathrm{~nm}$ in width and contained a nucleocapsid measuring on average $195.4 \mathrm{~nm}$ in length and $46.9 \mathrm{~nm}$ in width $(\mathrm{n}=40)$. Virion development appeared to be associated with double membrane-bound vesicles within the nuclei and rod-shaped filaments (Fig. 2e,f).

An intracytoplasmic inclusion in the Sertoli (nurse) cells of male gonads was recorded in Pacifastacus leniusculus from the Rivers Trent, Stour, Medway, Wharfe, Ribble and Bach Howey Stream. Infected tubules occurred in clusters within the testicular lobes, and in low level infections, the inclusions were 

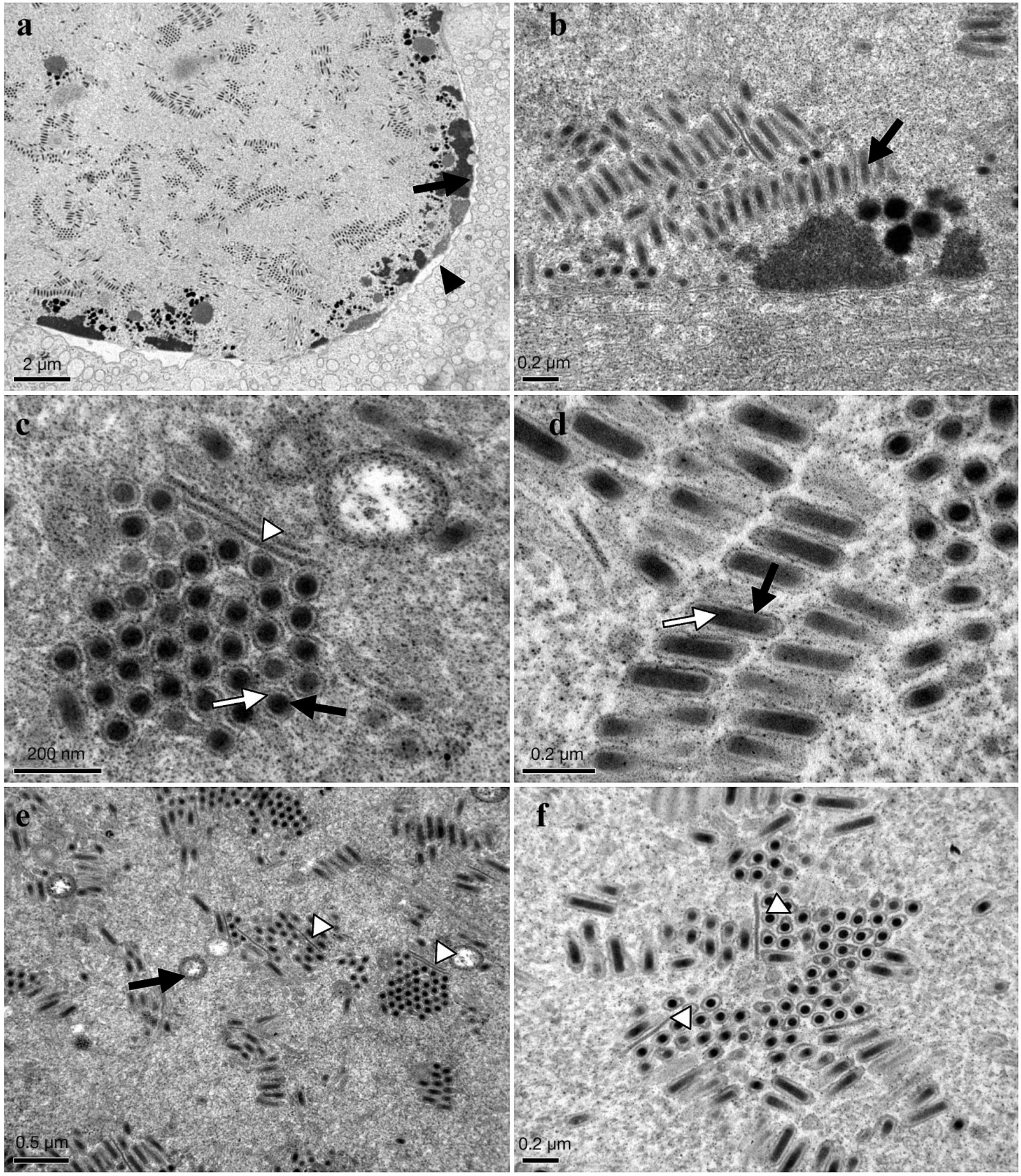

Fig. 2. Pacifastacus leniusculus bacilliform virus (PIBV) within epithelial cells of crayfish hepatopancreas tissues. Transmission electron microscopy (TEM). (a) Nucleus from a PlBV-infected cell containing rod-shaped bacilliform virions. Host chromatin is marginalised (arrow), and the nuclear membrane appears swollen (arrowhead). (b) Fully formed virions appeared to accumulate at the nuclear membrane in some nuclei, forming paracrystalline arrays (arrow). (c) Transverse section of virions, electrondense nucleocapsid (black arrow) can be seen within trilaminar membrane (white arrow). Note presence of rod-shaped filaments closely associated with developing virions (arrowhead). (d) Longitudinal section of rod-shaped virion consisting of an electron-dense nucleocapsid (black arrow) surrounded by a closely fitted trilaminar membrane (white arrow). (e) Virion development appeared to be associated with double membrane bound vesicles within the nuclei (arrow) and rod shaped filaments (white arrowheads). (f) Virion development appeared as rod-shaped filaments (white arrowheads) with fully formed virions accumulating around these structures within the nuclei 

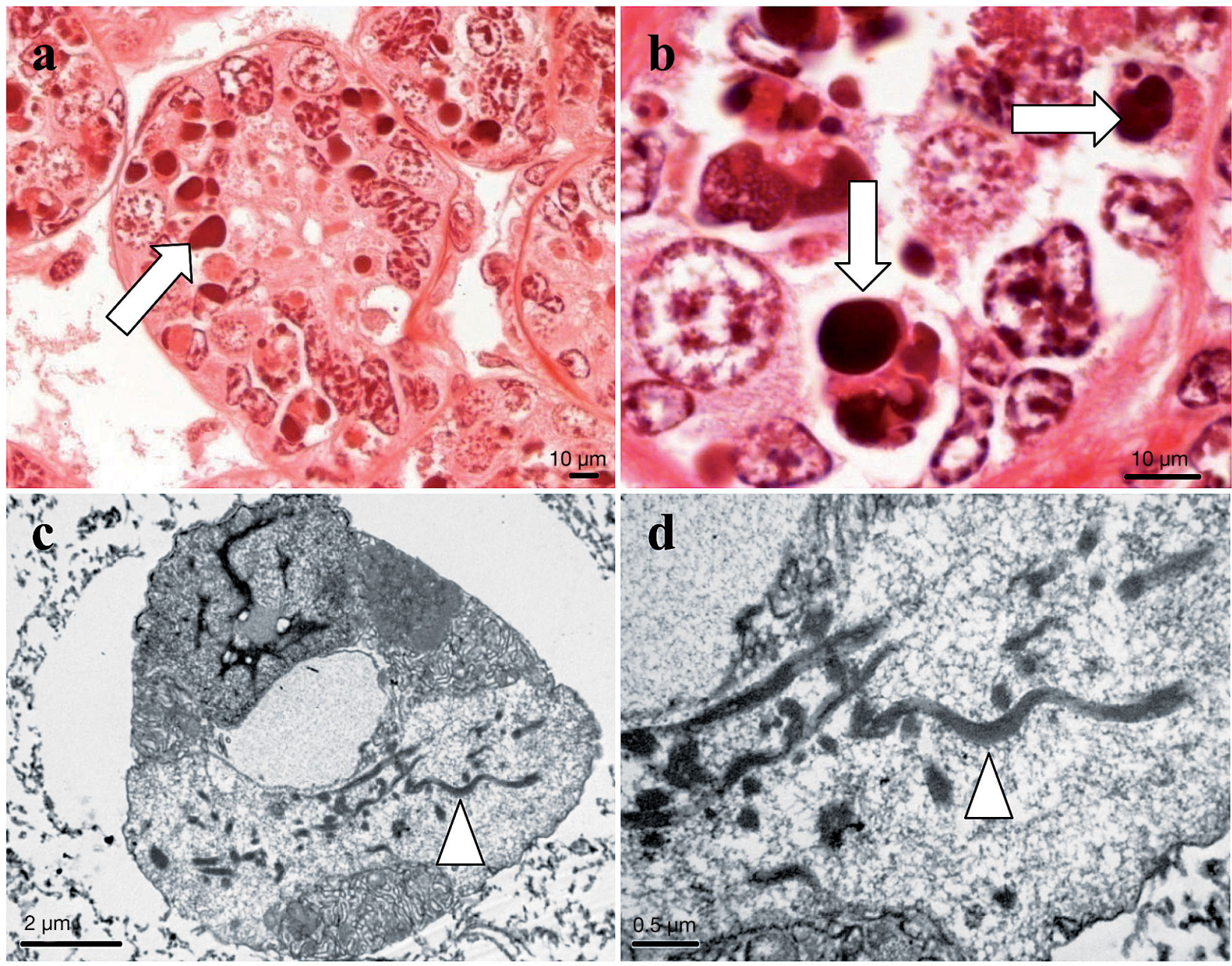

Fig. 3. Spiroplasma sp. infection of Pacifastacus leniusculus. (a) Low power view of gonadal tubule showing inclusion bodies (arrow) in the cytoplasm of a Sertoli cell. Note the lack of sperm within the lumen and the general degeneration of cells immediately surrounding infected cells. H\&E staining. (b) High power view of male gonad with infected Sertoli cells containing inclusion body (arrows). H\&E. (c) Single Sertoli cell with inclusion body containing helical structures in cytoplasm (arrow head). TEM. (d) High power view of Spiroplasma sp. in cytoplasm of inclusion body. Note obvious helical arrangement of Spiroplasma sp. (arrowhead). TEM

restricted to single lobes (Fig. 3a). The infection was absent from cells of the collecting ducts and the vas deferens. Mature sperm was generally absent from the lumens of affected tubules. Degeneration of the epithelial and Sertoli cells of the tubules occurred in latter stages of the infection (Fig. 3b). Ultrastructurally, a single, membrane-bound inclusion was noted in the cytoplasm of the Sertoli cells (Fig. 3c). Despite the use of material from wax blocks, the preservation was of sufficient quality to discern spiral-shaped organisms resembling Spiroplasma spp. within the inclusion that lacked a cell wall and measured $\sim 20 \mathrm{~nm}$ in diameter and 5 to $10 \mu \mathrm{m}$ in length (Fig. 3d). No dividing stages were noted.

Peritrichous ciliates were recorded in the gills of Pacifastacus leniusculus from all sites, with the exception of the River Bourne. No pathology was noted with these infections, although levels were considered low, with a maximum of 20 individual ciliates being visible in a histological section. A stalked ciliate on the legs and carapace was noted in $P$. leniusculus from 2 sites at a maximum prevalence of $29.6 \%$. Ectocommensal ostracods and mites were associated with the gills and legs of $P$. leniusculus from 8 and 2 sites, respectively. No pathology was noted with either of these ectocommensals.

Enteric bacteraemia typified by the presence of granulomas in the hepatopancreas tubules, and midgut epithelium was apparent in 7 samples of Pacifastacus leniusculus. In 2 animals, these granulomas had progressed to form large necrotic areas encapsulated by the deposition of melanin. Additionally, bac- 
teria were isolated from the haemolymph of $P$. leniusculus, including Aeromonas hydrophila, Hafnia alvei and Vibrio alginolyticus (Table 2); molecular sequencing of these isolates provided $>99 \%$ homology with these species and those recorded in the WUBlast2 database.

A total of 15 Orconectes virilis were caught in the Lee Navigation in October 2007. No infections were detected in these animals (Table 1). A total of 40 Astacus leptodactylus were collected from the River Lee in October 2007, and a further 16 were caught in the same river in May 2008 (see Table 1). A multiplate Psorospermium sp. was noted in the hepatopancreas, cuticular epithelium, gills and gonads of 25 A. leptodactylus in October 2007 and in the cuticular epithelium, muscle and gonads of 9 animals in May 2008 (Fig. 4a). Peritrichous ciliates were noted on the gills of 11 A. leptodactylus caught in May 2008. Pathology associated with the infection was negligible.

\section{Health status of captive non-native crayfish}

Summary data for infections detected in captive non-native crayfish are presented in Table 3. No histological evidence of infections was detected in 3 Cambarellus patzcuarensis obtained from a fish dealer in Northampton. However, the bacteria Aeromonas sobria, Citrobacter freundii and Weeksella virosa were isolated from 3 different individuals and identified using primary tests, API20E and API20NE (see Table 2). A low level infection with an Epistylislike organism was detected on the legs of the crayfish obtained from a dealer in Guildford and on 1 of 5 individuals from a dealer in Colchester. In addition, a single granuloma was noted in the hepatopancreas of a single crayfish from Guildford.

Cherax peknyi imported from Indonesia in August 2007 and from Singapore in September 2007 and April 2008 were seized at a port of entry. A multiplate Psorospermium sp. occurred in the gills, hepatopancreas and cuticular epithelium of 2 animals from Indonesia (Fig. 4b) and in the muscle of 1 C. peknyi from Singapore in September 2007 (Fig. 4c). A biplate Psorospermium sp. occurred in the gills, gonadal tissues, stomach, hepatopancreas, muscle and cuticular epithelium of $75 \%$ of the studied crayfish from Indonesia (Fig. 4d), in 10 individuals from Singapore collected in September 2007 (Fig. 4e) and in the gills, hepatopancreas and gonads of 4 individuals seized in April 2008. The biplate form did not co-occur with the multiplate form in any host. Unidentified temnocephalids were noted in the gills of $10 \%$ of the $C$. peknyi seized from Indonesia; no pathology was n.
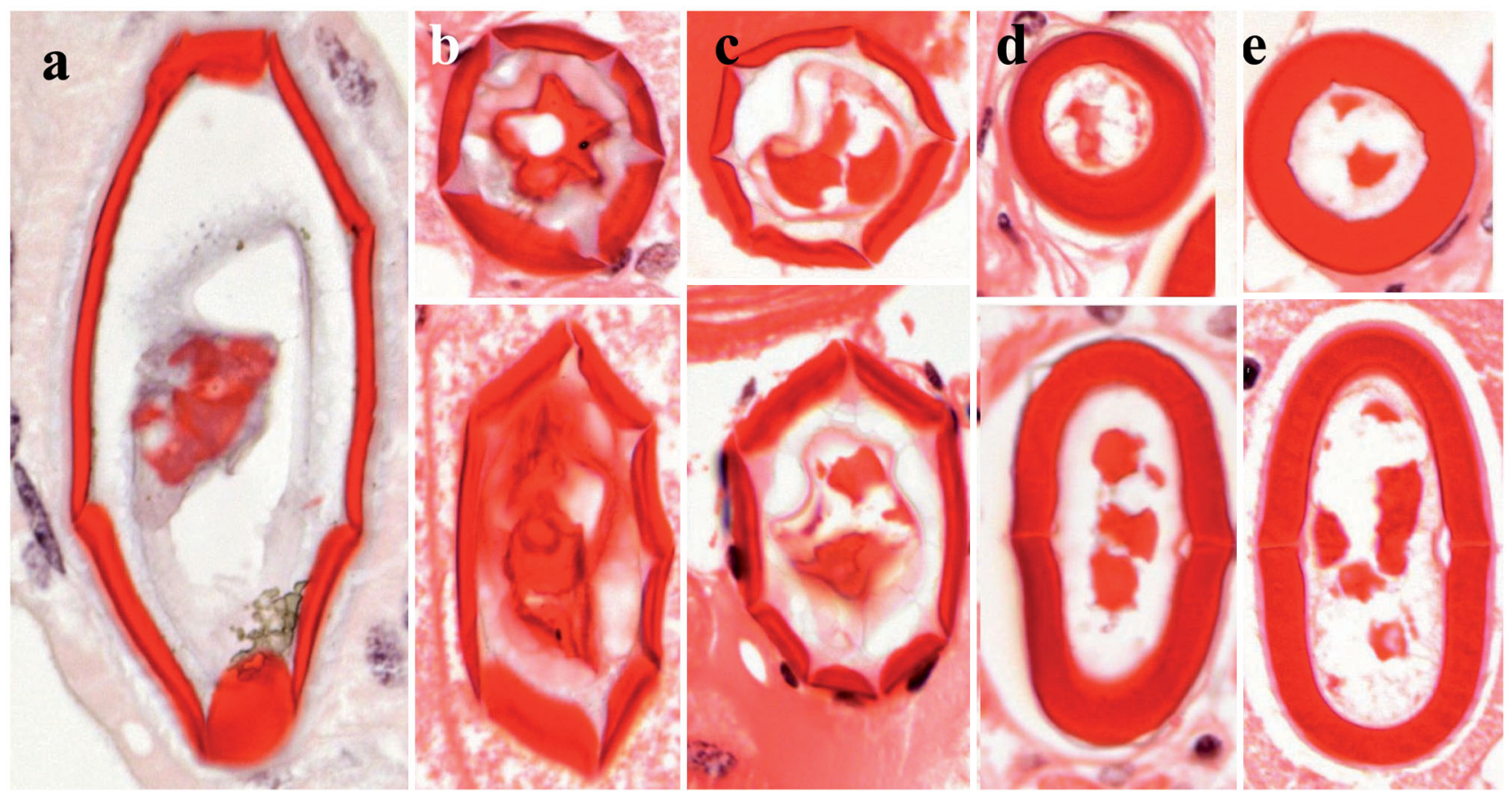

Fig. 4. Histological sections (H\&E stained) through Psorospermium spp. from multiple crayfish hosts. Multiplate form from (a) Turkish crayfish collected in the UK, (b) zebra crayfish imported from Indonesia, and (c) zebra crayfish imported from Singapore. Biplate form isolated from (d) zebra crayfish imported from Indonesia, and (e) zebra crayfish imported from Singapore. Transverse (top) and longitudinal (bottom) sections shown in (b) to (e); longitudinal section only shown in (a) 


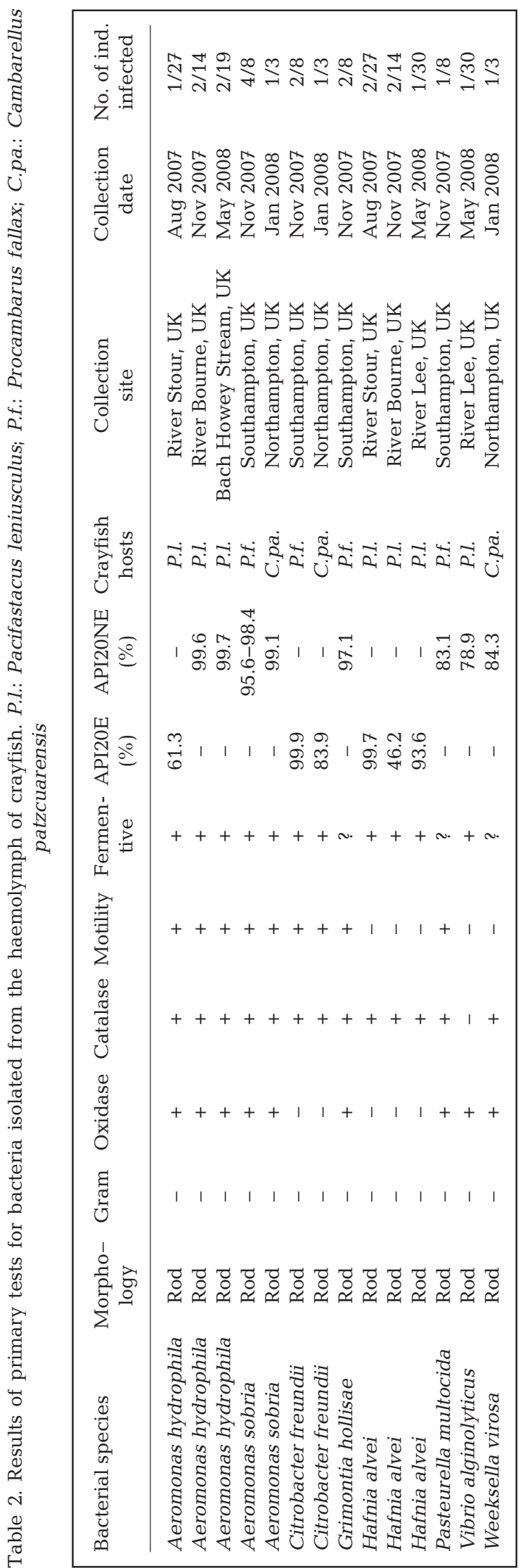

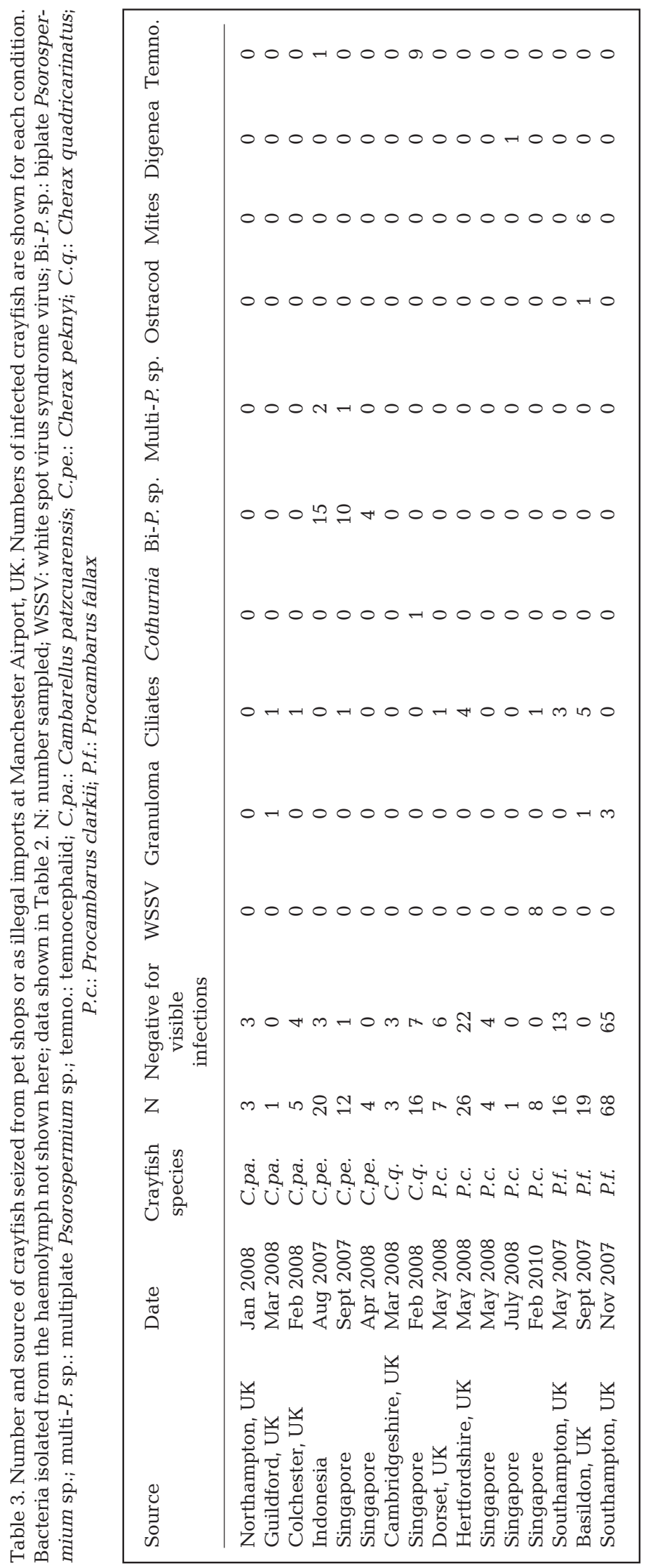





Fig. 5. Temnocephalid infection of Cherax quadricarinatus. (a) Entire temnocephalid removed from crayfish following fixation in Davidson's freshwater fixative. Five digitate tentacles are visible at anterior end of the animal (arrowhead), with the subterminal posterior adhesive disk marked with a black arrow. Two eyespots are also visible at the anterior end. Differential interference contrast (DIC) microscopy. (b) Histological section through 2 temnocephalids associated with the gills. Three of the 5 tentacles are seen in section (arrowhead) as well as posterior adhesive disk (arrows). H\&E. (c) High-power view through a single temnocephalid. Digitate tentacle marked with arrowhead and posterior adhesive disk (arrow) associated with gill. H\&E.

(d) Eggs of unidentified temnocephalid (arrow) associated with gills. H\&E

oted, whilst a low level peritrichous ciliate infection was recorded on the gills of a single $C$. peknyi from Singapore seized in September 2007.

No infections were detected in 3 Cherax quadricarinatus seized from a fish dealer in Cambridgeshire. The 9 C. quadricarinatus seized from a shipment from Singapore were infected with temnocephalids in the gills, and pathology was limited (Fig. 5). A concomitant low level Cothurnia-like infection was detected on the gills of 1 individual.

Peritrichous ciliates were noted on the gills of 4 out 26 Procambarus clarkii from an aquarium in Hertfordshire and on 1 out of 7 from Dorset. Infection levels were low, with the exception of 1 individual from Hertfordshire, which was found to have a particularly high number of peritrichous ciliates associated with the carapace. No other infections were detected in these samples. Four individuals illegally imported from Singapore in May 2008 were negative for infection, whilst 1 digenean was detected in the muscle of the $1 P$. clarkii imported from Singapore in July 2008. All 8 P. clarkii imported from Singapore in February 2010 were positive for infection with WSSV. The virus was noted histologically in all epithelial tissues. In particular, hypertrophied nuclei with obvious inclusions were found in the cuticular epithelium, gills and midgut epithelium (Fig. 6). Subsequent $\mathrm{PCR}$ and sequencing of the amplicon con- 

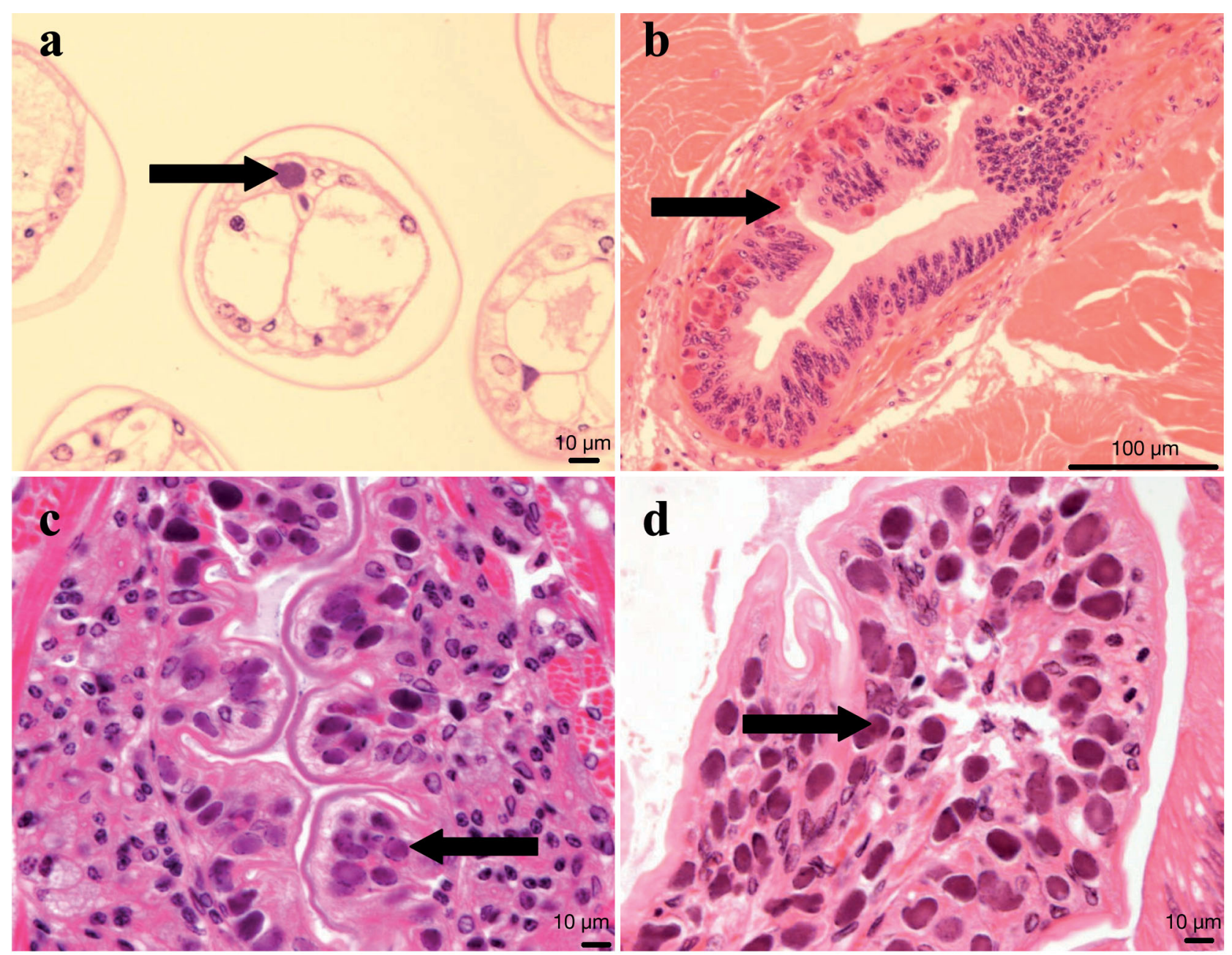

Fig. 6. Histology of white spot syndrome virus (WSSV) in Procambarus clarkii based on H\&E staining. (a) WSSV-infected nucleus in gill (arrow). (b) Low-power view of hindgut showing numerous infected nuclei (arrow). (c,d) Midgut epithelium nuclei with inclusions and emarginated chromatin clearly visible (arrow)

firmed the identity as WSSV in these individuals; peritrichous ciliates were noted in the gills of 1 crayfish at a low level.

Peritrichous ciliates were recorded on the gills of 3 Procambarus fallax from a fish dealer from Southampton in May 2007 and from 5 P. fallax from Basildon in September 2007. In addition, mites were detected on the gills of $6 \mathrm{P}$. fallax, and a single ostracod was noted in 1 individual seized from an aquarium in Basildon. Granulomas were recorded in the heart, hepatopancreas, gills and connective tissue of the gonads of 3 P. fallax seized from Southampton in November 2007. Haemolymph was only extracted from 8 marbled crayfish collected in Southampton. The bacteria identified using primary tests and API 20E or API 20NE included Citrobacter freundii, Aeromonas sobria, Grimontia hollisae and Pasteurella multocida. No other infections were recorded.

\section{DISCUSSION}

The present study is the first wide-scale survey of non-native crayfish species established in rivers or imported into mainland Britain and provides evidence that these animals are host to a small number of parasites, commensals and potential pathogens. The present study also demonstrated the presence of previously unrecorded novel infections in Pacifastacus leniusculus and Cherax peknyi. In the original description of $C$. peknyi by Lukhaup \& Herbert (2008), no pathogens or commensals were reported; the current study has identified the presence of 2 Psorospermium forms and an unidentified temnocephalid. However, this species was originally described from Papua New Guinea, while the samples examined in the current study were obtained from a shipment imported from Indonesia, and thus, 
it is not possible to determine where these animals became infected. Crayfish seized at a port of entry or in pet shops were found in almost all cases to carry innocuous or low level infections. However, their potential role in further mortalities of indigenous crayfish species is unknown. Importantly, the apparent absence of infections in these species provides further evidence of the potential success of these hosts if released into our waterways. In the event that the NICS were to be released into a watercourse in Britain, deliberately or otherwise, and assuming that the abiotic factors present are conducive to survival, the limited number of pathogens present would be advantageous to the NICS. Transmission of pathogens from NICS to ICS has been shown to occur, sometimes with dire consequences (Alderman 1993, Chinain \& Vey 1988, Ohtaka et al. 2005, Füreder et al. 2009, Volonterio 2009).

The most widespread and invasive crayfish species in Britain is Pacifastacus leniusculus, originally introduced from California, USA and Sweden for aquaculture purposes in 1976 (Holdich et al. 2009). Alderman (1993) suggested that although several of the original imports of signal crayfish from the USA were destined directly for quarantine facilities with limited possibility of disease transfer, others may have been imported directly from North America with no disease screening occurring and potentially without entering such facilities. Thus, at least some British populations are potentially derived directly from wild North American stocks. In its native range, however, signal crayfish have only been noted as hosts for a previously undescribed intranuclear bacilliform virus (Longshaw 2011) and for 2 branchiobdellids Sathodrilus attenuatus and Xironogiton victoriensis (Gelder \& Siddall 2001, Williams et al. 2009). X. victoriensis has subsequently been recorded on signal crayfish in Italy (Oberkofler et al. 2002), and both branchiobdellids were recorded in Japan following the introduction of signal crayfish into Japan (Ohtaka et al. 2005). In introduced areas, signal crayfish have been shown to carry or be susceptible to WSSV, Aeromonas hydrophila, Fusarium sp., Aphanomyces astaci, Psorospermium haeckeli, Thelohania contejeani and 3 undescribed microsporidia (Alderman et al. 1990, Diéguez-Uribeondo et al. 1993, Dunn et al. 2009). Signal crayfish are considered to be responsible for the spread of $A$. astaci across Europe (Lilley et al. 1997, Longshaw 2011).

In the current study, no visible infections were noted in two-thirds of the signal crayfish examined, and in the rest, few parasites, disease agents or commensals were noted. Thus, the surveyed signal cray- fish populations fulfil the criteria of being successful invaders with few detrimental pathogens limiting their survival. Furthermore, 5 of the 7 infections noted in this species during the current study are considered non-specific, including ciliates, ostracods and mites. Although these commensals were not identified to species, they are unlikely to be a major mortality driver for signal crayfish because the numbers were generally low and no pathology was noted. Torchin et al. (2003) suggested that on average successful invaders transfer 3 infections from their native range and acquire an average of 4 infections, a pattern that is mirrored in the current study.

The viral infection in signal crayfish appears to be similar to the B-virus in the shore crab Carcinus maenas, B2 virus in Carcinus mediterraneus and Baculo$\mathrm{B}$ in the blue crab Callinectes sapidus, all of which are viral infections of the haemocytes that show an association of the developing viral particles to vesicles within the nucleus (Johnson 1988). A presumptively identical virus, the Pacifastacus leniusculus bacilliform virus, was reported from signal crayfish in California by Hauck et al. (2001); because there has been no reciprocal transfer of signal crayfish from Europe to the USA, it seems probable that the virus infection was introduced into Britain with imports of signal crayfish directly from North America. The wider distribution of the virus in signal crayfish in Britain and across Europe is unknown and deserves further investigation. Whilst similar bacilliform viruses have been noted in other crayfish species, they are all likely to represent distinct virus species with strict host specificity (Longshaw 2011). With the exception of the Cherax quadricarinatus-bacilliform virus (CqBV), apparently causing mortality (Romero \& Jiménez 2002), intranuclear bacilliform viruses in crayfish do not appear to be particularly detrimental to their hosts (Edgerton et al. 1996, Edgerton 2003).

A novel Spiroplasma-like organism causing marked pathology in the gonadal tissue of male crayfish in several populations was noted. Sperm production in the affected animals was compromised, and the pathology of the infected tubule was marked. Whilst it has not been possible in the current study to fully assess the effect of the infection on fecundity or survival, Spiroplasma spp. have been reported in a number of plant and animal hosts, and some are considered to act as male killing agents, distorting sex ratios (Nienhaus \& Sikora 1979, Regassa \& Gasparich 2006). In freshwater Crustacea, including crayfish, Spiroplasma spp. have been associated with mortality (Nunan et al. 2005, Wang et al. 2010). The relationship between the Spiroplasma sp. detected in the 
current study and the systemic form reported in Procambarus clarkii by Wang et al. (2005) needs to be elucidated, and thus, further work, including experimental transmission trials, 16SrRNA sequencing, serology and ultrastructural studies on material collected specifically for TEM, will be required to fully characterise this infection. The wider distribution and origin of the Spiroplasma of signal crayfish is unknown, and in particular, the role of the bacteria as a biological control agent or as a barrier for the invasion success of signal crayfish throughout its range needs consideration.

Virile crayfish Orconectes virilis were found to be negative for any visible infections in the current study. Virile crayfish were first recorded in Britain in a concrete-lined pond on the River Lee system in 2004 and thought to be due to the illegal disposal of the animals by a local householder (Ahern et al. 2008). The crayfish have subsequently successfully migrated into adjacent watercourses some $7 \mathrm{~km}$ away from the original point of release in that system; in the Netherlands, the species has become established in several hundreds of kilometres of waterway (Holdich et al. 2009). It is interesting to speculate that the successful establishment and movement of the virile crayfish in the Lee catchment is due in part to a lack of disease agents. However, with the exception of a report of a Thelohania sp. in Canada (France \& Graham 1985, Graham \& France 1986), of 2 branchiobdellids in Canada (Williams et al. 2009) and evidence of susceptibility to WSSV (Davidson et al. 2010), no data exist on the pathogens of virile crayfish in its native range, making it difficult to unequivocally attribute its success to a lack of pathogens compared with its native range.

In contrast, Astacus leptodactylus has been shown to be susceptible to at least 6 fungal agents, approximately different 12 protists, a Psorospermium sp. and branchiobdellids in its native range (Edgerton et al. 2002, Fard et al. 2011, Longshaw 2011). Although $A$. leptodactylus has been recorded in a number of sites in mainland Britain, to date, no concerted disease survey of the species has been carried out. In the current study, they were only visibly infected with Psorospermium sp. in the sample taken in October 2007 and with Psorospermium sp. and peritrichous ciliates in the sample taken in May 2008; both of these parasites or commensals are relatively nonspecific. Thus, the almost complete absence of visible infections in this population compared with the wide range of infections noted in its native range strongly suggest that its successful invasion and establishment is in part due to the absence of pathogens.
The relative absence of pathogens in Cherax quadricarinatus in the current study is of concern because in its native range, it has been recorded as a host for at least 8 different viral infections, 6 ciliate species, at least 5 species of temnocephalids, bacteria, fungi and Psorospermium (Herbert 1988, Eaves \& Ketterer 1994, Edgerton \& Owens 1999, Edgerton et al. 2000, La Fauce \& Owens 2007, Owens \& McElnea 2000). However, in areas outside its native ranges where it is considered a pest species (Belle et al. 2011), limited pathogens have been recorded (Hauck et al. 2001, Romero \& Jiménez 2002, Volonterio 2009, Longshaw 2011), which supports the enemy release hypothesis. In the current study, the animals obtained from a pet shop were negative for infections, whilst the shipment from Singapore only contained temnocephalids and a single example of a ciliate infection of the gills. This species has become established in a number of water catchments in Singapore (Ahyong \& Yeo 2007), and whilst not expressly commented on by those authors, it is interesting to speculate on its success in Singapore being due to an absence of pathogens.

The potential introduction of the EC Directive 2006/88 listed pathogen WSSV (Stentiford et al. 2010) through the importation of Procambarus clarkii is a real risk, with clear histological and molecular evidence of the virus in crayfish from Singapore. In its native and introduced range, $P$. clarkii is susceptible to the virus (Yan et al. 2007, Baumgartner et al. 2009). Even at low water temperatures, the virus is able to replicate, although at a lower rate than at higher temperatures (Du et al. 2008), and thus, it could establish with devastating consequences if introduced into the British Isles. However, current legislation does not limit the numbers of crayfish destined for the aquarium trade that are imported into Britain. Furthermore, there is no requirement for exporting nations to demonstrate freedom from notifiable diseases, such as WSSV, if animals are destined for the aquarium trade or for human consumption (see Stentiford et al. 2010 for context). Thus, the risk of importation of exotic pathogens via this route requires further analysis.

The current study has shown that established and imported non-native crayfish in mainland Britain tend to have a limited number of pathogens present, and with the possible exception of a viral and Spiroplasma infection, most of the pathogens are innocuous and are non-specific. The success of signal crayfish, introduced into mainland Britain in the 1970s for aquaculture purposes, is in part explained by the lack of pathogens present, in direct support of the 
enemy release hypothesis. However, the pathogens present in its native range must be examined to determine if the successful invasion of the host throughout Europe is due to the lack of pathogens or some other factor. Further studies are required for all species imported into Europe to determine baseline data on the pathogens across their range and to confirm that the diseases of non-indigenous crayfish species in their new range are limited compared with their indigenous range. Successful invaders appear to have fewer pathogens.

Acknowledgements. We thank T. Hill, R. Hicks and M. Green from the Centre for Environment, Fisheries \& Aquaculture Science (Cefas) for technical support, members of the Cefas Fish Health Inspectorate, the Environment Agency and riparian owners for assisting in the collection of crayfish around the British Isles and B. Oidtmann for supplying site details for signal crayfish collected in September 2009. The work was funded by the UK Department for Environment, Food and Rural Affairs through contracts FC1168, FA001 and FB001.

\section{LITERATURE CITED}

Ahern D, England J, Ellis A (2008) The virile crayfish, Orconectes virilis (Hagen, 1870) (Crustacea: Decapoda: Cambaridae), identified in the UK. Aquat Invasions 3: 102-104

Ahyong, S, Yeo, D (2007) Feral populations of the Australian red-claw crayfish (Cherax quadricarinatus von Martens) in water supply catchments of Singapore. Biol Invasions 9:943-946

Alderman DJ (1993) Crayfish plague in Britain, the first twelve years. Freshw Crayfish 9:266-272

> Alderman DJ, Holdich D, Reeve I (1990) Signal crayfish as vectors in crayfish plague in Britain. Aquaculture 86:3-6

Baumgartner WA, Hawke JP, Bowles K, Varner PW, Hasson KW (2009) Primary diagnosis and surveillance of white spot syndrome virus in wild and farmed crawfish (Procambarus clarkii, $P$. zonangulus) in Louisiana, USA. Dis Aquat Org 85:15-22

Belle CC, Yeo DCJ (2010) New observations of the exotic Australian red-claw crayfish, Cherax quadricarinatus (Von Martens, 1868) (Crustacea: Decapoda: Parastacidae) in Singapore. Nature in Singapore 3:99-102

> Belle CC, Wong JQH, Yeo DCJ, Tan SH, Tan HH, Clews E, Todd PA (2011) Ornamental trade as a pathway for Australian redclaw crayfish introduction and establishment. Aquat Biol 12:69-79

> Bi K, Huang H, Gu W, Wang J, Wang W (2008) Phylogenetic analysis of Spiroplasmas from three freshwater crustaceans (Eriocheir sinensis, Procambarus clarkia and Penaeus vannamei) in China. J Invertebr Pathol 99: 57-65

> Calvo-Ugarteburu G, McQuaid CD (1998) Parasitism and introduced species: epidemiology of trematodes in the intertidal mussels Perna perna and Mytilus galloprovincialis. J Exp Mar Biol Ecol 220:47-65

Chinain M, Vey A (1988) Experimental study of Fusarium solani: infections in Astacus leptodactylus and Pacifasta- cus leniusculus (Crustacea, Decapoda). Dis Aquat Org 5:215-223

Clay K (2003) Parasites lost. Nature 421:585-586

- Davidson EW, Snyder J, Lightner D, Ruthig G, Lucas J, Gilley J (2010) Exploration of potential microbial control agents for the invasive crayfish, Orconectes virilis. Biocontrol Sci Technol 20:297-310

> Dick JTA, Armstrong M, Clarke HC, Farnsworth KD and others (2010) Parasitism may enhance rather than reduce the predatory impact of an invader. Biol Lett 6:636-638

Diéguez-Uribeondo J, Pinedo-Ruiz J, Cerenius L (1993) Presence of Psorospermium haeckeli (Hilgendorf) in a Pacifastacus leniusculus (Dana) population of Spain. Freshw Crayfish 9:286-288

> Du H, Dai W, Han X, Li W, Xu Y, Xu Z (2008) Effect of low water temperature on viral replication of white spot syndrome virus in Procambarus clarkii. Aquaculture 277: 149-151

> Dunn JC, McClymont HE, Christmas M, Dunn AM (2009) Competition and parasitism in the native white clawed crayfish Austropotamobius pallipes and the invasive signal crayfish Pacifastacus leniusculus in the UK. Biol Invasions 11:315-324

Eaves LE, Ketterer PJ (1994) Mortalities in red claw crayfish Cherax quadricarinatus associated with systemic Vibrio mimicus infection. Dis Aquat Org 19:233-237

Edgerton BF (2003) Further studies reveal that Austropotamobius pallipes bacilliform virus (ApBV) is common in populations of native freshwater crayfish in southeastern France. Bull Eur Assoc Fish Pathol 23:7-12

Edgerton BF, Owens L (1999) Histopathological surveys of the redclaw freshwater crayfish, Cherax quadricarinatus, in Australia. Aquaculture 180:23-40

Edgerton BF, Paasonen P, Henttonen P, Owens L (1996) Description of a bacilliform virus from the freshwater crayfish, Astacus astacus. J Invertebr Pathol 68:187-190

> Edgerton BF, Webb R, Anderson IG, Kulpa EC (2000) Description of a presumptive hepatopancreatic reovirus, and a putative gill parvovirus, in the freshwater crayfish Cherax quadricarinatus. Dis Aquat Org 41:83-90

Edgerton BF, Evans LH, Stephens FJ, Overstreet RM (2002) Synopsis of freshwater crayfish diseases and commensal organisms. Aquaculture 206:57-135

Fard AN, Motalebi AA, Jafari BJ, Meshgi MA, Azadikhah D, Afsharnasab M (2011) Survey on fungal, parasites and epibionts infestation on the Astacus leptodactylus (Eschscholtz, 1823), in Aras Reservoir West Azarbaijan, Iran. J Fish Sci 10:266-275

Feria TP, Faulkes Z (2011) Forecasting the distribution of Marmorkrebs, a parthenogenetic crayfish with high invasive potential, in Madagascar, Europe, and North America. Aquat Invas 6:55-67

> France RL, Graham L (1985) Increased microsporidian parasitism of the crayfish Orconectes virilis in an experimentally acidified lake. Water Air Soil Pollut 26:129-136

> Füreder L, Summerer M, Brandstätter A (2009) Phylogeny and species composition of five European species of Branchiobdella (Annelida: Clitellata: Branchiobdellida) reflect the biogeographic history of three endangered crayfish species. J Zool 279:164-172

> Gelder SR, Siddall ME (2001) Phylogenetic assessment of the Branchiobdellidae (Annelida, Clitellata) using 18S rDNA, mitochondrial cytochrome $c$ oxidase subunit I and morphological characters. Zool Scr 30:215-222

Gelder SR, Delmastro GB, Rayburn JN (1999) Distribution of 
native and exotic branchiobdellidans (Annelida: Clitellata) on their respective crayfish hosts in northern Italy, with the first record of native Branchiobdella species on an exotic North American crayfish. J Limnol 58:20-24

Graham L, France R (1986) Attempts to transmit experimentally the microsporidian Thelohania contejeani in freshwater crayfish (Orconectes virilis). Crustac Int J Crustac Res 51:208-211

Hauck AK, Marshall MR, Li JKK, Lee RA (2001) A new finding and range extension of bacilliform virus in the freshwater red claw crayfish in Utah, USA. J Aquat Anim Health 13:158-162

> Herbert BW (1988) Infection of Cherax quadricarinatus (Decapoda: Parastacidae) by the microsporidium Thelohania sp. (Microsporida: Nosematidae). J Fish Dis 11: 301-308

Holdich DM, Reynolds JD, Souty-Grosset C, Sibley PJ (2009) A review of the ever increasing threat to European crayfish from non-indigenous crayfish species. Knowledge Manag Aquat Ecosyst 394-395:1-46

- Johnson PT (1988) Rod-shaped nuclear viruses of crustaceans: hemocyte-infecting species. Dis Aquat Org 5: $111-122$

La Fauce K, Owens L (2007) Investigation into the pathogenicity of Penaeus merguiensis densovirus (PmergDNV) to juvenile Cherax quadricarinatus. Aquaculture 271: 31-38

> Lilley JH, Cerenius L, Söderhäll K (1997) RAPD evidence for the origin of crayfish plague outbreaks in Britain. Aquaculture 157:181-185

Longshaw M (2011) Diseases of crayfish: a review. J Invertebr Pathol 106:54-70

Lukhaup C, Herbert B (2008) A new species of freshwater crayfish (Crustacea: Decapoda: Parastacidae) from the Fly River drainage, western province, Papua New Guinea. Mem Qld Mus 52:213-219

Martin P, Dorn NJ, Kawai T, van der Heiden C, Scholtz G (2010) The enigmatic Marmorkrebs (marbled crayfish) is the parthenogenetic form of Procambarus fallax (Hagen, 1870). Contrib Zool 79:107-118

- Mayén-Estrada R, Aladro-Lubel MA (2001) Distribution and prevalence of 15 species of epibiont peritrich ciliates on the crayfish Cambarellus patzcuarensis Villalobos, 1943 in Lake Pátzcuaro, Michoacán, Mexico. Crustaceana 74:1213-1224

> Nienhaus F, Sikora RA (1979) Mycoplasmas, spiroplasmas, and Rickettsia-like organisms as plant pathogens. Annu Rev Phytopathol 17:37-58

Nunan LM, Lightner DV, Oduori MA, Gasparich GE (2005) Spiroplasma penaei sp. nov., associated with mortalities in Penaeus vannamei, Pacific white shrimp. Int J Syst Evol Microbiol 55:2317-2322

Oberkofler B, Quaglio F, Fureder L, Fioravanti ML, Giannetto S, Morolli C, Minelli G (2002) Species of Branchiobdellidae (Annelida) on freshwater crayfish in south Tyrol (northern Italy). Bull Fr Peche Piscic 367:777-784

Ohtaka A, Gelder S, Kawai T, Saito K, Nakata K, Nishino M (2005) New records and distributions of two North American branchiobdellidan species (Annelida: Clitellata) from introduced signal crayfish, Pacifastacus leniusculus,

Editorial responsibility: Victor Meyer-Rochow,

Bremen, Germany in Japan. Biol Invasions 7:149-156

OIE (Office International des Epizooties) (2009) Diagnostic manual for aquatic animal diseases, 6th edn. OIE, Paris

> Owens L, McElnea C (2000) Natural infection of the redclaw crayfish Cherax quadricarinatus with presumptive spawner-isolated mortality virus. Dis Aquat Org 40: 219-223

Quaglio F, Morolli C, Galuppi R, Tampieri MP and others (2006) Sanitary-pathological examination of red swamp crayfish (Procambarus clarkii, Girard 1852) in the Reno Valley. Freshw Crayfish 15:1-10

> Regassa LB, Gasparich GE (2006) Spiroplasmas: evolutionary relationships and biodiversity. Front Biosci 11: 2983-3002

> Reynolds ES (1963) The use of lead citrate at high pH as an electron-opaque stain in electron microscopy. J Cell Biol $17: 208-212$

Romero X, Jiménez R (2002) Histopathological survey of diseases and pathogens present in redclaw crayfish, Cherax quadricarinatus (Von Martens), cultured in Ecuador. J Fish Dis 25:653-667

Savini D, Occhipinti-Ambrogi A, Marchini A, Tricarico E, Gherardi F, Olenin S, Gollasch S (2010) The top 27 animal alien species introduced into Europe for aquaculture and related activities. J Appl Ichthyol 26:1-7

Stentiford GD, Scott A, Oidtmann B, Peeler E (2010) Crustacean diseases in European legislation: implications for importing and exporting nations. Aquaculture 306:27-34

Torchin ME, Lafferty KD, Kuris AM (2001) Release from parasites as natural enemies: increased performance of a globally introduced marine crab. Biol Invasions 3: 333-345

> Torchin ME, Lafferty KD, Dobson AP, McKenzie VJ, Kuris AM (2003) Introduced species and their missing parasites. Nature 421:628-630

Vogt G, Tolley L, Scholtz G (2004) Life stages and reproductive components of the Marmorkrebs (marbled crayfish), the first parthenogenetic decapod crustacean. J Morphol 261:286-311

> Volonterio O (2009) First report of the introduction of an Australian temnocephalidan into the New World. J Parasitol 95:120-123

> Wang W, Gu W, Ding Z, Ren Y, Chen J, Hou Y (2005) A novel Spiroplasma pathogen causing systemic infection in the crayfish Procambarus clarkii (Crustacea: Decapod), in China. FEMS Microbiol Lett 249:131-137

Wang W, Gu W, Gasparich GE, Bi K and others (2011) Spiroplasma eriocheiris sp. nov., a novel species associated with mortalities in Eriocheir sinensis, Chinese mitten crab. Int J Syst Evol Microbiol 61:703-708

> Watson T, Fulker MJ, Cook MG (1972) Reprocessing of waxembedded tissue blocks for the electron microscope applied to Crohn's disease. J Clin Pathol 25:914-916

Williams BW, Gelder SR, Proctor H (2009) Distribution and first reports of Branchiobdellida (Annelida: Clitellata) on crayfish in the Prairie Provinces of Canada. West N Am Nat 69:119-124

> Yan DC, Dong SL, Huang J, Zhang JS (2007) White spot syndrome virus (WSSV) transmission from rotifer inoculum to crayfish. J Invertebr Pathol 94:144-148

Submitted: November 8, 2011; Accepted: February 17, 2012 Proofs received from author(s): May 22, 2012 